\title{
On the Enterprise Management Mode in Higher Vocational Colleges
}

\author{
Wang Libing \\ Jinzhong vocational and technical college \\ Jinzhong City, Shanxi, China \\ wanglibinjiaoshou@163.com \\ Dan Qiang \\ Suzhou Industrial Park Institute of Vocational \\ Technology \\ Jinzhong City, Shanxi, China
}

\author{
Liu Yuehong \\ Jinzhong vocational and technical college \\ Jinzhong City, Shanxi, China \\ Cao Chengguang \\ Jinzhong vocational and technical college \\ Jinzhong City, Shanxi, China
}

\begin{abstract}
To solve the problem of "de-administration", higher vocational colleges must establish the enterprise management mode. First, change the idea, set up service-oriented administration, and regard itself as "enterprise", and the student as the "product". Second, implement the enterprise management, carry out the implementation of flat enterprise organization system, and decrease the administrative influence. Then, adopt the "project-oriented" enterprise training mode, and cancel the department-level system and optimize the course content considering the ability requirement on the professionals requirements, to enhance the professional competence of students in the real work environment, in this regard, the "enterprise" operating mechanism could be regulated, and the development of vocational schools further promoted. The innovation lies in enterprise management model adopted in the higher vocational colleges.
\end{abstract}

Keywords—education, de-administration, enterprization

\section{INTRODUCTION}

This paper is one of the results of the "establishment of enterprise-type institutions, strengthen the autonomy of vocational colleges" in 2014-2015 annual project topics of scientific research planning project in the Chinese Society of Vocational and Technical Education

The essence of Vocational colleges lies in the vocational and technical education [1], and higher vocational aims to foster the specialized personnel with the high-level application skills. However, many vocational colleges have deviated from the essential attributes of higher vocational colleges. They are just like the undergraduate colleges with a large administrative bureaucracy organization, and the service consciousness is very poor. It is very easy to hurt the initiatives and enthusiasm of the teachers, which greatly hinders the development of institutions. The enterprise management could be adopted by higher vocational colleges to " de-administration" and reduce the negative impact of administrative factors on vocational education, [2] enhance the vocational ability of students and promote the development of vocational colleges.

\section{CHANGE IDEAS AND ESTABLISH A SERVICE-ORIENTED ADMINISTRATIVE ORGANIZATION}

Prof. Yen Peter adopted the SDP method, which is the abbreviation of Serve, Develop and Profit. He explained that "Service is the price of future and must focus on the future development". SDP always puts the service in the first place, and illustrates that the profit in the future could be achieved only if the best quality service is provided [3] "SDP" can also be applied to the administration and student management in higher vocational institutions.

If the higher vocational colleges are regarded as a "business", then its products are students, vocational colleges should establish a brand image, focus on the perspective of the education stakeholders, such as business and students to improve the "product" quality. Vocational colleges and universities shall cultivate the talent that Enterprises and the market needs,. The enterprise management mode of the higher vocational colleges could also show the flexibility of higher education and vocational colleges to adapt to environmental capacity. [4] The government should change its functions and serve mainly. Higher vocational college management should service-oriented. The important criteria to measure the quality of vocational education depends on whether the needs of students are satisfied, and the school goal to cultivate high-end skilled talents achieved.

\section{FLAT ORGANIZATION OF THE ENTERPRISE SYSTEM}

Classical management school thought that efficiently complete organizational tasks are required, "efficiency is fundamental element to measure any organization." Weber's "bureaucracy" is described the power level within the organization's. In fact, administrative power and academic power face the serious dislocation, leading to now the corruption of many vocational colleges academics, and severe bureaucratic consciousness of administrative organs. [5]

To make administration decision-making more accurate in a timely manner, it is necessary to decrease the administrative 
influencer, simplify the administrative organization, implement the flat organization form, reduce the excessive management level, form the high-efficiency management organization, move down the center of gravity, combine the centralization and decentralization.

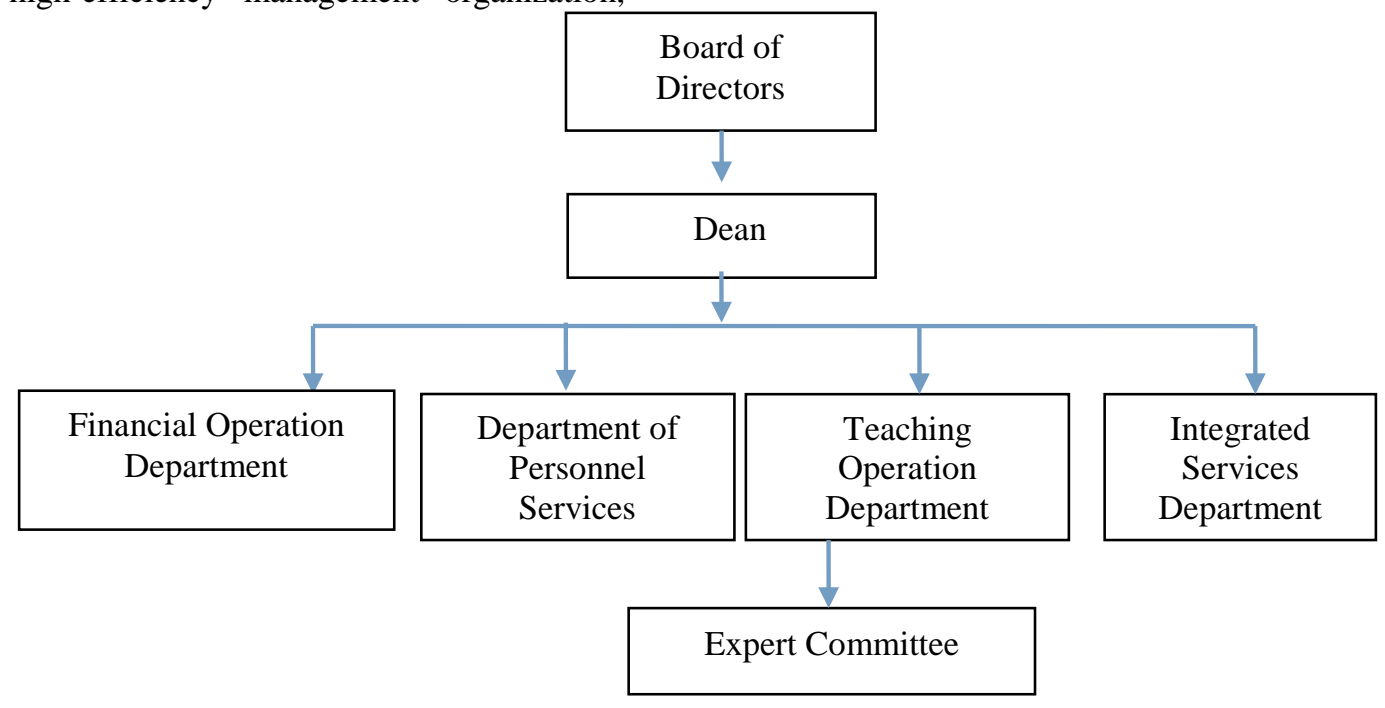

Fig. 1. Flat Organization Chart of Higher Vocational

[2002] No. 16, the national councils decision on promoting the transformation of professional education also clearly put forward "to promote the management system and school system reform," encourage and enterprises to build higher vocational schools together and form multi-participatory and multi-evaluation operating mechanism. Now there are a few public vocational colleges and universities participating in the school board of directors.

Suzhou Industrial Park Institute of Vocational Technology, as a national model institution, whose members of the board of directors include: 27 companies, directors of multinational corporations, Alumni Association and Parent Council. The Board of Directors regularly listens to the work report of the College, reviews the work of the College, makes positive suggestions on the work of the College, and provides instructive decision-making opinions on major problems in the construction and development of the College.

Shenzhen Vocational and Technical Education Consortium Board of Directors is the decision-making body of the Consortium, and a board of directors is set and taken by the vice mayor in charge of education, several directors are taken by the representative member from the department of education, labor, finance, economy, planning and other administrative departments and the business community and the education sectors. The governing bodies, advisory bodies and supervisory bodies of the consortium of vocational and technical education shall be in the form of committees, each with one chairman, two vice-chairmen and several members, among which fulltime staff and part-time staff each shall account for a certain proportion of part-time staff which may be taken by the relevant professionals in the community.

The selection process of dean shall be open to the public and the dean selection criteria shall be jointly developed by the government departments and school professors, the dean is responsible for all teaching, research and administrative matters.

"European university academic values are embodied in the autonomy and academic freedom." [6] Vocational colleges shall have the independence and freedom of enterprises, and the main affairs shall be discussed and adopted by the Professor Committee composed of experts. Without the consent of the professors, even the board of directors can't make any decisions. [7] Department of teaching and operation are managed by the Committee of Experts, composed of leaders of the discipline democratic recommended by the professors to actively attract professionals with rich practical experience in every professional field into the education and teaching process, give full play to their potential in the professional settings, training objectives, and teaching, so that academic power and administrative power are balanced. As for the appointment and removal of teachers, it shall be approved by the Committee of Experts.

\section{PROJECT - ORIENTED "ENTERPRIZATION - Cultivation" Teaching Mode}

"Enterprization training" achieve seamless connection between higher vocational colleges and enterprises to speed up the role conversion from "students" to "professional people", and fully embody the characteristics of higher vocational education. [8]

Higher vocational colleges should take the employment as the direction and construct the practice curriculum system with "post core competence" as the goal, along with the "modularization" course system and "project oriented", regard curriculum and education as products and services, take the work process as the guidance, optimize the course content considering the job ability requirements . Train intelligent, comprehensive, technical application personnel, and take market, occupation, technology as the coordinate axis into 
consideration, to comprehensively set the professional competence and caliber coverage.

First of all, the professional team of teachers shall go to the industry and enterprise production line every year, understand and track of the actual work tasks of enterprises; invite skilled personnel of enterprises and institutions to participate in the college curriculum, make repeated demonstration and discussion, select the typical tasks in business to connect between the curriculum and the vocational skills standards to make students learn while doing. Make "curriculum integration" to strengthen cooperation between schools and enterprises to achieve the connection between course content and professional standards to form curriculum system which better suits the market and job requirements, improve the quality of teaching, and foster the practical talents for the market.

Jinhua Vocational and Technical College revokes the original department-level system, business department, project department, studio and other professional-level basic structure with characteristics of school-enterprise integration set up, providing a more open platform and broad vision. [9] Higher Vocational College Teaching is mainly project-oriented, and it is also required to cancel the department-level system, for example, some $\mathrm{E}$ - commerce major belongs to information technology major, others belong to the Department of Electronic Engineering, in fact, its curriculum covers many departmental courses, in addition to Professional knowledge, it also contains cultural knowledge in the foundation department , legal knowledge of the law department, marketing knowledge in the Department of Economic and Trade Department , financial knowledge, management knowledge in the business management department, and Logistics knowledge in the Electronic Department ... Canceling the system can facilitate the integration of teachers Resources, so that students learn useful, sufficient, practical knowledge.

Course set shall be in full accordance with business standards for vocational skills, such as the set courses for the information engineering major, teachers in the cultural class will not take the major connection into consideration, even if the set of the software courses, those who teach PHOTOSHOP or FLASH will not take into account whether the pre-class and Follow-up course, or the professional direction is biased in favor of animation or studio or advertising design, teaching separately, and it seems that students have learned a lot of software, but they can't complete one work. They have low vocational ability, and it can't meet the needs of student development, which is hard to meet the requirements of enterprises.

For example, the main production process of the animation is 1 , planning, script, characters, scenes, props 2, model, material, texture sound 3, binding, lens preview 4, action, coloring, synthesis 5, rendering, editing, output. The collection of learning work tasks should help improve students' comprehensive ability to face the task in the future. Teachers of the cultural class should teach the writing of the script according to professional needs, rather than take the same usual teaching of practical writing as that in the past. Software classes should be focused on each specific job which is all divided into a number of relatively independent work responsibilities, each job can be seen as the comprehensive ability taken when engaged in the job to ensure that students can complete the project in the real Work environment.

\section{STANDARDIZE THE "ENTERPRISE" OPERATING SYSTEM}

The structure of higher vocational colleges should make effective checks and balances with multi - interactive and multi - party evaluation. Improve the operation mechanism of the board of directors, formulate and improve the relevant policies and regulations, abolish the administrative level of higher vocational colleges, and realize the separation of administration and teaching, and management and schooling. Change the internal management of the university management model to form the democratic management, and common governance. The Board shall establish a regular meeting system, implement the scope of the Board's proceedings and determine which powers are vested in the Board.

Monitoring Committee is an independent body, and must make sure the independent monitoring and evaluation to ensure the effectiveness of decision-making implementation without the influence of every execution layer, in particular, not directly intervened by the higher institutions, but according to the requirement of market, society and enterprise, eliminating the cumbersome procedures requested instructions to improve the efficiency of the supervision and make more directional, just and transparent supervision. [10]

On the one hand, Harvard University "dual board" is composed of the "legal persons" by the president of the college, the financial director and the other five members, but the college rule regulates that its order must be recognized by the "board of director"

Shenzhen Vocational and Technical Education Consortium adopt Management Committee Chair Responsibility System under the leadership of board of Director. The implementation of "a team of two brands", the management committee is set up separately, but also it could in the form of the joint work, attracting a wide range of community participating in decisionmaking, advice and supervision of the vocational schools

\section{CONCLUSION}

Clark illustrated in Creating an Enterprise University: An Organizational Approach to Change: "Enterprise spirit is not what the university has achieved until now, and this spirit is even more obvious in universities where, in the traditional European context, the university will get rid of the strict standards of government regulation and departments to seek opportunities in the market and make tentative changes.” Higher vocational colleges shall implement enterprise management, truly" de-administrative ", and better adapt to the opportunities and space in the institution brought by the changes in the market.

\section{REFERENCES}

[1] Chen Bosong. Exploration on Modern vocational education - eight years of practice in Shenzhen Vocational and Technical College [M]. South China University of Technology Press .2001,3 
[2] Jiang Hualin, Wang Ping. "positive" and"security" on university deadministration [J]. Higher Education of Sciences, 2011 (2): 13 - 18.

[3] Li Jiahua. The proper way of entrepreneurship - undergraduate entrepreneurship guidance [M].: Higher Education Press . Beijing 2011 (7): 47

[4] Wen Zhengbao, transformation of higher education on the spirit of enterprise - enterprise and enlightenment on Enterprise University [J], Zhejiang Institute of Education, 2007,1: Page 5

[5] Liao Xiaoping. Three questions on the administrative of university [J]. China Higher Education Research, 2013,9,

[6] [Cananda] Xumeide. Chinese University 1895 - 1995:Cultural Conflict in aCentury $[\mathrm{M}]$. translated by $\mathrm{Xu}$ Jie.: Educational Science Press, Beijing ,2000. 19.
[7] Zhu Hao 1, Chen Juan 2 See the reform of the administrative in an university from the historical evolution of American university governance [J], Journal of Hubei University (Philosophy and Social Sciences)

[8] Wang Zhanhong, Li Shaoming, Education practice and exploration of higher vocational on entreprization cultivation [J], Journal of Wuhan Institute of Technolgoy Engineering, 2006, 3: 1)

[9] Wang Zhenhong. The Quality Culture Leadership of Higher Vocational Colleges and its Promotion Path [J]. Educational Research .2013 (1): 113

[10] Meng Xiuli, Enlightenment of Australian certificate framework to the professional construction of vocational schools in China [J], Vocational Education Forum, 2012,09: 94 